\title{
Distribution of Aedes albopictus Mosquitoes in Indonesia
}

\author{
Desi Heriawati \\ Universitas Islam Negeri \\ Mataram, Indonesia \\ desi.heriawati@uinmataram.ac.id \\ Sri Sofiati Umami \\ Universitas Islam Negeri \\ Mataram, Indonesia \\ sofie.umami@uinmataram.ac.id
}

\author{
Dadan Supardan \\ Universitas Islam Negeri \\ Mataram, Indonesia \\ dadan.supardan@uinmataram.ac.id
}

\author{
Suhirman \\ Universitas Islam Negeri \\ Mataram, Indonesia \\ suhirman@uinmataram.ac.id
}

\begin{abstract}
Among the primary vectors of infections agent involved in the case of dengue epidemic, are the Culicidae-insect, Aedes albopictus, capable of introducing themselves in urban core. This study performed a survey mosquitos species by catching their egg using ovitrap installed within seven regions in residential area of Sandubaya District, Lombok, Indonesia. The collected samples were identified and was analyzed its abundance then mapped using geographical information system. The most abundance of Ae. albopictus was found in Selagalas and Abian Tubuh with relative abundance value were $100 \%$ and 97.5\% respectively. Spatial analysis showed that the site with highest abundance of Ae. albopictus presented lowest species distribution (15\%). This finding was associated with densities population and existence of home industry which was centered at certain sites. This such an environment provides infesting are for dengue vector, thus surveillance for controlling dengue vector in those areas is a necessary.
\end{abstract}

Keywords: Aedes albopictus, dengue vector, geographic information system

\section{INTRODUCTION}

Dengue hemorrhagic fever (DHF) is one of the health problems that can cause death. An estimated 2.5 billion people in the world are at risk of contracting the dengue virus. Data from all over the world shows Asia fulfills the order first in the number of DHF sufferers every year. Tropical countries in Asia such as Southeast Asia are included in the endemic area of dengue hemorrhagic fever (DHF), one of which is Indonesia (Andriani, 2016). The World Health Organization (WHO) noted Indonesia as a country with the highest DHF cases in Southeast Asia. Based on data from the Indonesian Ministry of Health in 2014-2016, there were 201,885 cases of dengue fever spread throughout the province, with 77.96 Incidence Rate (IR) or morbidity rate per 100,000 populations, $0.79 \%$ of the Case Fatality or death rate and there were 1,585 cases caused death (Kemenkes, 2016).

DHF is an endemic disease caused by dengue virus transmitted by mosquito vectors (Andriani, 2016). The main vector of DHF is Aedes aegypti and
Aedes albopictus mosquitoes as secondary vectors. Both vectors are spread throughout Indonesia including West Nusa Tenggara. Based on data from the West Nusa Tenggara Provincial Health Service (NTB), in 2016 dengue cases reached 1,939 people spread in 10 districts / cities in NTB. Most cases were reported in the City of Mataram, East Lombok and Sumbawa District (Kesehatan Provinsi, 2014). Cases of dengue fever are increasing each year. Based on data obtained specifically from all regions in the city area of Mataram, Sekarbela and Sandubaya sub-districts are the area's most commonly found in dengue cases.

The level of DHF cases in an area is influenced by several factors, including environmental conditions, population mobility, population density, the presence of artificial or natural containers in landfills (TPA) or in other waste bins as well as community behavior. The higher the level of population density, population mobility, the availability of many containers in landfill sites and other places and the low level of community knowledge in controlling DHF can cause increased cases of DHF in the local community (Fathi, 2005).

In dealing with these various factors, environmental management needs to be done as one of the efforts to control the spread of DHF. One of the Aedes mosquito control methods implemented in several countries is by mapping or geographical mapping to find out areas that have high potential in the spread of DHF so that various prevention efforts can be carried out. The mapping technique that is often used today is the Geographic Information System (GIS).

GIS is a geographic information system that describes a state of "space" or region or known as spatial (spatial analysis). GIS is able to show spatially the distribution of patients and their patterns of spread. By using a map between the condition of the location with the distribution of patients, it can also be predicted that the location is potentially endemic and dangerous. One study on the use of GIS has been done by Sumunar (2007), showing that 
in the east is bordered by Lingsar District and Narmada District in West Lombok.

The research in Sandubaya Subdistrict was conducted in all Region namely Mandalika, Babakan, Turida, Bertais, Abian Tubuh, Selagalas and Dasan Cermen villages with the same number of sampling points in each Region, namely 10 points, with 20 ovitrap counts, bringing the total number of ovitrap points to 20 taking is 70 points Based on the results of research conducted in Sandubaya Subdistrict in each village, it can be seen that the distribution of Aedes albopictus in the region varies in each region. From these results we get the following data:

Table 1.Collected samples of Aedes albopictus mosquitoes in Sandubaya District, Lombok a study titled "Mapping of Aedes albopictus in Sandubaya District, Mataram City Using Geographic Information Systems (GIS) as the Basis for Controlling Dengue Fever" which is expected to help the process of controlling DHF in the region.

\section{METHOD}

This research was descriptive observational with ecological study approach (ecological studies). The research was conducted in Sandubaya District, Mataram City. Samples were collected from 7 villages, namely Abian Tubuh Baru, Babakan, Bertais, Turida, Mandalika, Selagalas and Dasan Cermen. Ovitrap were placed in residential area for a week, then the collected samples were taken to the laboratory for identification. The sampling technique used was purposive sampling. The collected samples in this study were include eggs, larvae, pupae and mosquito imago. The abundance of Aedes albopictus was determined.

\section{RESULTS AND DISCUSSION}

\section{A. Map of Research Sampling}

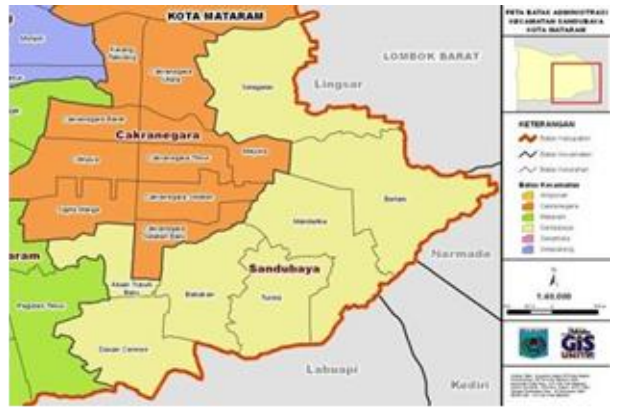

Figure 1. Map of Sandubaya District-Site of Sampling of Mosquito

Sandubaya is one of the sub-districts in the city of Mataram. Sandubaya District has an area of 10.32 $\mathrm{km}^{2}$ with an astronomical location of 11730 '- 118 30' East Longitude and between 0554 '- 08 04' 'South Latitude. Sandubaya District in the south is bordered by Labuapi District in West Lombok and north is bordered by Cakranegara District, while in the west it is bordered by Mataram and Cakranegara District and

\begin{tabular}{|c|c|c|c|c|c|c|}
\hline \multirow[b]{2}{*}{$\begin{array}{l}\mathbf{N} \\
\mathbf{0}\end{array}$} & \multirow[b]{2}{*}{ Region } & \multicolumn{3}{|l|}{ Total } & \multicolumn{2}{|c|}{ Abiotic Factor } \\
\hline & & $\begin{array}{l}\text { Larva } \\
\text { e }\end{array}$ & $\begin{array}{l}\text { Pup } \\
\text { a }\end{array}$ & $\begin{array}{l}\text { Imag } \\
\text { o }\end{array}$ & $\begin{array}{l}\text { Averag } \\
\text { e Temp }\end{array}$ & $\begin{array}{l}\text { Aver } \\
\text { age } \\
\text { Light } \\
\text { Inten } \\
\text { sity }\end{array}$ \\
\hline 1 & $\begin{array}{l}\text { Mandalik } \\
\text { a }\end{array}$ & 85 & 0 & 0 & 28,40 & $\begin{array}{l}4499 . \\
80\end{array}$ \\
\hline 2 & Babakan & 466 & 21 & 0 & 27,60 & $\begin{array}{l}4555 . \\
10\end{array}$ \\
\hline 3 & Turida & 140 & 8 & 0 & 27,50 & $\begin{array}{l}4852 . \\
50\end{array}$ \\
\hline 4 & Selagalas & 57 & 0 & 0 & 26,00 & $\begin{array}{l}3455 . \\
30\end{array}$ \\
\hline 5 & $\begin{array}{l}\text { Abian } \\
\text { tubuh }\end{array}$ & 519 & 66 & 6 & 30,10 & $\begin{array}{l}1087 \\
2,00\end{array}$ \\
\hline 6 & $\begin{array}{l}\text { Dasan } \\
\text { Cermen }\end{array}$ & 127 & 7 & 0 & 31,00 & $\begin{array}{l}1600 \\
0.20\end{array}$ \\
\hline 7 & Bertais & 13 & 0 & 0 & 28,20 & $\begin{array}{l}1683, \\
00\end{array}$ \\
\hline
\end{tabular}

Table 2. Distribution of Aedes albopictus mosquitoes in Sandubaya District, Lombok

\begin{tabular}{llcl}
\hline No & Region & $\begin{array}{l}\text { Relative } \\
\text { Abundance } \\
\text { Index (\%) }\end{array}$ & $\begin{array}{l}\text { Availability } \\
\text { Frequency } \\
(\boldsymbol{\%})\end{array}$ \\
\hline $\mathbf{1}$ & Mandalika & 17,31 & 40 \\
\hline $\mathbf{2}$ & Babakan & 33,92 & 75 \\
\hline $\mathbf{3}$ & Turida & 60,41 & 55 \\
\hline $\mathbf{4}$ & Selagalas & 100 & 15 \\
\hline $\mathbf{5}$ & Abian Tubuh & 97,52 & 80 \\
\hline $\mathbf{6}$ & Dasan Cermen & 58,26 & 25 \\
\hline $\mathbf{7}$ & Bertais & 18,05 & 65 \\
\hline
\end{tabular}

Based on Table 1, we can know that the highest number of Aedes albopictus individuals is in the Abian Tubuh Village, which is 519 larvae, 66 pupae and 6 images. The least amount of Aedes albopictus distribution was found in Bertais Village, which was 13 larvae and there were no pupae and imago found in the Region. Based on the identification results using a stereo microscope, there were 3 genus of mosquitoes spread in Sandubaya District, namely the genera Aedes, Anopheles and Culex as shown in the following figure 2 . 
(IKR) is classified into three categories: high (> $20 \%)$, moderate $(15 \%-20 \%)$, and low $(<15 \%)$. Based on this reference, it can be seen that Mandalika Urban Village is the village with the lowest IKR value, but is categorized as medium because it has a IKR with a value of $17.31 \%$. while other villages have relatively high IKR values above $20 \%$. Selagalas is a village that has the highest IKR value, reaching $100 \%$. Of all the sampling points in the Selagalas area, only Aedes albopictus species were found.

A

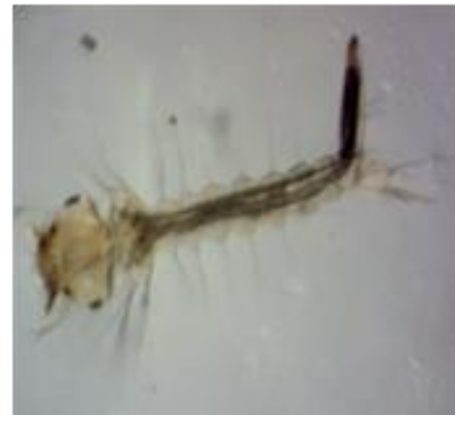

B

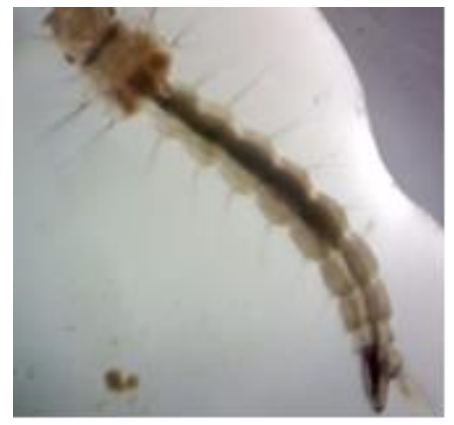

C

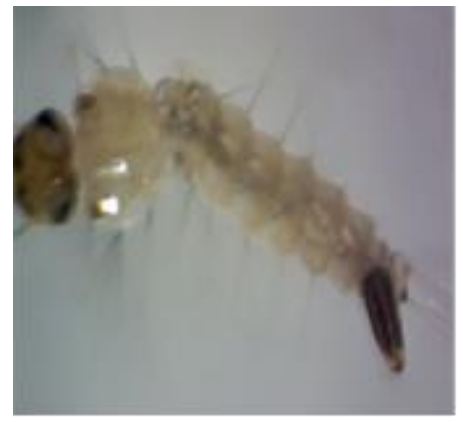

D

Figure 2. Images of larvae of trapped mosquitos in Sandubaya district: A. Anopheles; B. Culex sp., C. Aedes albopictus, D. Aedes aegypti

The Relative Density Index (IKR) is a comparison of the number of individuals of a species to the total number of individuals found. According to Krebs (1989), the value of the relative abundance index
Therefore, the comparison of the number of Aedes albopictus individuals to the total number of individuals is $100 \%$.

In Table 2, the frequency data of income also varies from village to village. Based on the table of highest frequency of Aedes albopictus species found in Abian Tubuh, that is $80 \%$, while the lowest frequency of frequency is found in Selagalas, which is $15 \%$.

Based on observations, each village has a different distribution of mosquitoes. High and low of the species density in each region allegedly influenced by various factors in the form of biotic and abiotic factors. This opinion is in line with the results of research conducted by Jacob (2014), which states that the development of Aedes sp mosquitoes is influenced by biotic and abiotic factors.

Aedes albopictus mosquito larvae were most commonly found in Abian Tubuh Village with a total of 519 larvae, 66 pupae, and 6 images. In this Site the average temperature is around $300 \mathrm{C}$ and the average light intensity is $10872 \mathrm{~lx}$. The smallest number of Aedes albopictus individuals was found in Bertais Urban Village, with a total of 13 larvae and no pupae and imago in the total ovitrap. The average temperature in the Region was recorded at $28.200 \mathrm{C}$ and the light intensity was $1683 \mathrm{~lx}$. The difference in distribution abundance is thought to be influenced by various factors, including habitat, ovitrap type, attractant type, temperature, population density, the existence of landfills (TPA), availability of containers, light intensity and the behavior of surrounding communities. This assumption is in line with the results of Yudhastuti's (2005) study, which states that environmental conditions, the existence of containers and people's behavior influence the presence of mosquito larvae.

\section{A. Types of Attractants}

In addition to the type of ovitrap, the abundance of mosquito vectors that can be collected is also thought to be influenced by the type of attractant used. The types of attractants that have been used are from cow dung mixed with water with a concentration of $10 \%$. Based on research conducted by Wiriastusi (2012), reported that the more effective media to be used as a solution in ovitrap is media 
mixed with cow dung compared to other contaminated media that have been used such as soapy water, rice washing water, water mixed with chicken manure, water mixed with horse dung and water mixed with soil.

\section{B. Population Density}

From the whole observed area, it is known that the quantity and type of mosquito larvae obtained varies in each Region. Based on data obtained in the field, ovitraps placed in dense, less clean and slumdwelling environments are found to have more mosquito larvae compared to environments that have low dwelling densities and are clean. One of the villages that has a fairly dense population density and settlement pattern is the Abian Tubuh and Babakan villages. Both villages have a vector index that is quite high compared to other villages. This illustrates that the factor of population density is also thought to affect the density and abundance of Aedes albopictus vectors in a region. This is in accordance with the results of Oktikasari's (2008) study, which said that the density of occupancy can affect the presence of mosquito vectors.

\section{Water Reservoir (TPA) and the Presence of Containers}

A water reservoir (TPA) is one of the places favored by Aedes albopictus. The existence of landfill in an environment is very important in the Aedes albopictus income index. The more there is landfill in an environment, it is suspected that the greater the opportunity for increased vector in the area. Data obtained from the study area provides information that villages that have many water reservoirs especially those used by residents have a high abundance index such as Abian Tubuh, Babakan and Turida villages which have a frequency value of $80 \%, 75$ respectively $\%$ and $55 \%$. The results of this study are in line with research by Fathi (2005), which states that the presence of water reservoirs has a role in the density of Aedes mosquitoes.

Sandubaya District is one of the Districts that has the largest local market and business center in the City of Mataram. The existence of a large market does not only cause a lot of landfills, but also can provide more containers originating from the rest of the goods being traded and can then become mosquito vector breeders. support the high vector density.

Based on the results of Azizah's research (2010), reported that the presence of containers of more than 3 containers has a risk of experiencing DHF 6.75 times greater than respondents who have containers of less than 3. The data illustrates that the presence of containers is very important to the presence of dengue vector, one of them is Aedes albopictus. The results of the study are in accordance with the results of observations that have been made. The environment that rarely has containers like Region Selagalas has a frequency of at least $15 \%$ when compared to other Region which have an average income index above $25 \%$.

\section{Light Temperature and Intensity}

Based on the data in Table 4.3, it is estimated that the density and abundance of Aedes albopictus species in a region can be influenced by temperature factors, as the results of research from several previous researchers such as Rahayu (2012), which states that there are several climatic elements that influence dominant in the incidence of DHF, one of which is temperature. At certain temperatures DHF vectors can develop optimally. Optimal temperature for the development of Aedes albopictus based on research conducted by Rahayu (2012), reported that the optimal temperature for the development of Aedes albopictus is $28-32 \mathrm{oC}$. From this statement it can be seen that the number of Aedes albopictus is affected by temperature. Most larvae were obtained in Abian Tubuh Village with an average temperature in the region around $300 \mathrm{C}$, which is the optimal temperature for the development of Aedes albopictus.

In addition to temperature, light intensity is also thought to affect the activity and presence of Aedes albopictus. The species is more often in environments that have low light intensity compared to environments with high light intensity. This is consistent with the results of research by Waluyo (2011), which states that the Aedes mosquitoes are more commonly found and are more active in carrying out activities at lower light intensities.
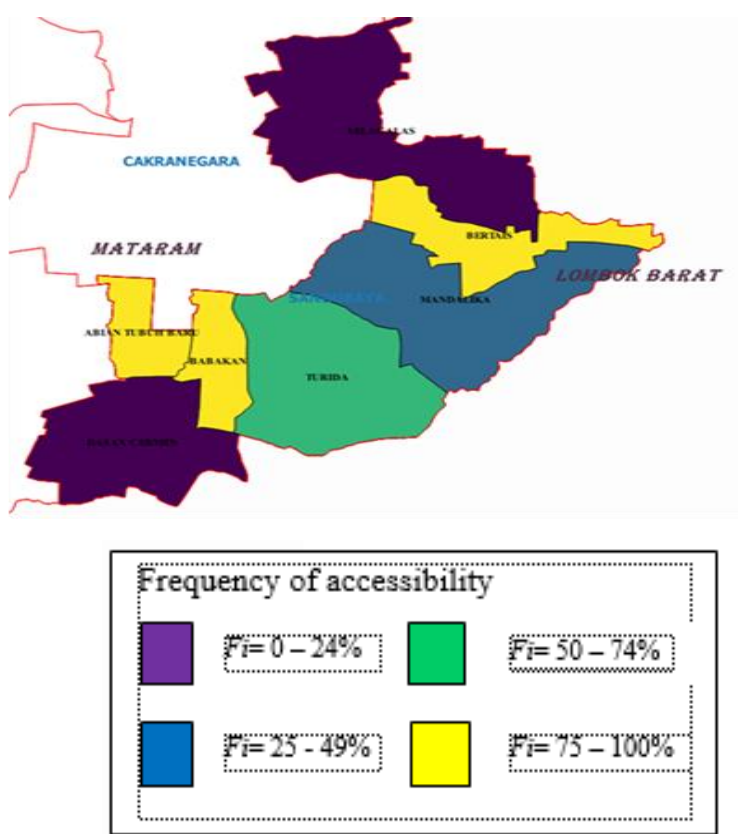

Figure 3. Distribution of Dengue vector, Aedes albopictus. 


\section{E. Community Behavior}

Community behavior play an important role in the presence of mosquito vectors in the surrounding environment. Community behavior is strongly supported by knowledge from the community in the region. The higher education and knowledge about the existence, factors and impacts caused by the presence of DHF vectors, the higher the awareness and seriousness of the community to make efforts to prevent the existence of these vectors. One effort that can be done is the movement to eradicate mosquito nests, abate, fogging, reflane use and others.

Based on the data obtained, we can observe the frequency of income from all Regions, describing that Selagalas Region are those that have the lowest income frequency of $15 \%$ and a relative abundance index of $100 \%$. This result is strongly supported by the results of research by Cahyo (2006) and Monintja (2015), which state that the level of knowledge and behavior of the community can influence the existence of the DBD vector.

\section{F. Rainfall}

Rainfall is a determining factor in the availability of mosquito breeding places. Enough rain will cause standing water in some water reservoirs which are mosquito breeding grounds. the highest number of rainy days in Sandubaya District occurred in November, which was around 25 days. Therefore, research conducted in November is also expected to be influenced by the high rainfall. high rainfall can support the percentage of vector vectors especially in the Region area, with many containers available such as Abian Tubuh, Babakan and Bertais.

\section{G. Geographic Information System (GIS)}

Geographic Information System (GIS) is a special information system that manages data that has spatial information (spatial reference). In a narrow sense, GIS is a computer system that has the ability to build, store, manage and display information of geographical significance, for example data identified by location, in a database. The results of mapping the distribution of Aedes albopictus mosquitoes in Sandubaya District in 2017 using GIS are as follows:

Based on Figure 2, it can be seen that the map illustrates the distribution of the Aedes albopictus vector in Sandubaya Subdistrict vary in each Region. Abian Tubuh Village is the Village with the highest Frequency of Density (Fi) of $80 \%$, then followed by the Babakan Village with a value $(\mathrm{Fi})$ of $75 \%$. Mandalika and Turida villages have $40 \%$ and $55 \%$ respectively, while Selagalas and Dasan Cermen are the lowest (Fi) with $15 \%$ and 25\%, respectively. Based on the map, it can be seen the results of the mapping of the distribution of Aedes albopictus illustrates that Sandubaya Subdistrict is classified as a high-risk area for Dengue Hemorrhagic Fever (DHF).

\section{CONCLUSION}

The spread of Aedes albopictus in the Sandubaya Subdistrict of Mataram City varies in each village. The frequency of density ( $\mathrm{Fi}$ ) is in the Abian Tubuh village which is $80 \%$ and the lowest is in the Selagalas village which is $15 \%$. Abundance of Aedes albopictus in Sandubaya District also varies. The highest Relative Abundance Index (IKR) is found in Selagalas Village which is $100 \%$ while the lowest frequency of occurrence is in Mandalika Urban Village which is $17.31 \%$. Thus, it can be seen that the people of Sandubaya Subdistrict have high potential of Dengue Hemorrhagic Fever (DHF). Therefore it is necessary to control efforts by looking at the potential of Aedes albopictus vector in mapped regions.

\section{REFERENCES}

[1] Andriani, N. W. E., "Tjitrosantoso. H., Paulina V \& Yamlean. Y., "Kajian Penatalaksanaan Terapi Pengobatan Demam Berdarah Dengue (DBD) Pada Penderita Anak Yang Menjalani Perawatan Di Rsup Prof. Dr. R.D Kandou Tahun 2013", Jurnal Ilmiah Farmasi. 2014. 3 (2): 57 - 61

[2] Andri, R., Gunawan. T \& Juwono M., "Tingkat Kerawanan Demam Berdarah Dengue Berdasarkan Sistem Informasi Geografi Dan Penginderaan Jauh Di Kota Banjar Propinsi Jawa Barat", Jurnal Ekologi Kesehatan. 2013. 12(2): 72 81

[3] Anwar, C., Lavita. R.A \& Handayani. D., "Identifikasi dan Distribusi Nyamuk Aedes Sp. Sebagai Vektor Penyakit Demam Berdarah Dengue di Beberapa Daerah di Sumatera Selatan", Majalah Kedokteran Sriwijaya. 2014. 46 (2): 111 $-117$

[4] Boesri, H. "Biologi dan Peranan Aedes albopictus (Skuse) 1894 sebagai Penular Penyakit", Aspirator. 2011.3 (2): 117 $-125$

[5] Budiyanto, A., "Perbedaan Warna Kontainer Berkaitan dengan Keberadaan Jentik Aedes aegypti di Sekolah Dasar", Jurnal Biotek Medisiana Indonesia. 2012.1 (2): 65-71

[6] Cahyo, K.," Kajian Faktor - Faktor Dalam Keluarga yang mempengaruhi Pencegahan Penyekit Demam Berdarah Dengue (DBD) di Region Metesh Kota Semarang”, 2006. Media Litbang Kesehatan. 16(4): 9

[7] Fadilla, Z. Hadi. U. K \& Setiyaningsih.S., "Bioekologi vektor demam berdarah dengue (DBD) serta deteksi virus dengue pada Aedes aegypti (Linnaeus) dan Ae. albopictus (Skuse) (Diptera: Culicidae) di Region endemik DBD Bantarjati, Kota Bogor", Jurnal Entomologi Indonesia. 2015. 12 (1): $31-38$

[8] Fakhriadi, R., Yulidasari. F \& Setyaningrum. R., "Faktor Risiko Penyakit Demam Berdarah Dengue Di Wilayah Kerja Puskesmas Guntung Payung Kota Banjarbaru (Tinjauan Terhadap Faktor Manusia, Lingkungan, Dan Keberadaan Jentik", Jurnal Publikasi Kesehatan Masyarakat Indonesia. 2015. 2 (1): 7 - 14

[9] Farajollahi, A \& Dana C., "A Rapid Identification Guide for Larvae of the Most Common North American ContainerInhabiting Aedes Species of Medical Importance", Journal of the American Mosquito Control Association. 2013. 29(3): $203-213$

[10] Fathi, Keman. S \& Wahyuni. C. U., "Peran Faktor Lingkungan Dan Perilaku Terhadap Penularan Demam Berdarah Dengue Di Kota Mataram", Jurnal Kesehatan Lingkungan. 2005. 2 (1): $1-10$

[11] Gama, A. T., "Analisis Faktor Risiko Kejadian Demam Berdarah Dengue Di Desa Mojosongo Kabupaten Boyolali”, Eksplanasi. 2010. 5 (2): 9 
[27] Rueda, L.M., "Pictorial keys for the identification of mosquitoes (Diptera: Culicidae) associated with Dengue Virus Transmission(Zootaxa 589)", New Zealand. Magnolia Press. 2004:1 - 60

[28] Rosa, E., "Studi Tempat Perindukan Nyamuk Vektor Demam Berdarah Dengue di Dalam Dan di Luar Rumah di Rajabasa Bandar Lampung", Jurnal Sains MIPA.2007. 13 (1) : $57-60$

[29] Rosilawati, H \& Zairil. J., Seasonal abundance of Aedes albopictus in selected urban and suburbaewn areas in Penang, Malaysia”, Tropical Biomedicine. 2007. 24(1): 83 94

[30] Sari. P., Martini \& Ginanjar, P., Hubungan Kepadatan Jentik Aedes Sp Dan Praktik PSN Dengan Kejadian DBD Di Sekolah Tingkat Dasar Di Kota Semarang", Jurnal Kesehatan Masyarakat. 2012. 1 (2): 413 - 422

[31] Sitorus, H., "Peng Amatan Larva Aedes Di Desa Sukaraya Kabupaten Oku Dan Di Dusun Martapura Kabupaten Oku Timur Tahun 2004”, Media Litbang Kesehatan 2007. 17(2): 28

[32] Suhardiono, "sebuah analisis faktor resiko perilaku masyarakat terhadap kejadian demam berdarah dengue (DBD) di Region Helvetia tengah, Medan", 2005" Jurnal mutiara kesehatan Indonesia. 2005. 1 (2): 1 - 7

[33] Subra, R., "Biology And Control Of CulexPipiens Ulnquefasciatus" Say, 1823 (Diptera, Culicidae) With Special Reference To Africa", Intsect Science Applicofion. 1981. 1 (4): 250 - 340

[34] Sukowati, S., "Masalah Vektor Demam Berdarah Dengue dan Pengendaliannya di Indonesia", Buletin Jendela Epidemiologi. 2010:20 -28

[35] Tairas, S., "Analysis of Implementation of Control of Dengue Hemorrhagic Fever in North Minahasa Regency", Jurnal Ilmu Kesehatan Masyarakat Umum. 2015.5 (1): 22 28

[36] Widjaja, J., "Keberadaan Kontainer sebagai Faktor Risiko Penularan Demam Berdarah Dengue di Kota Palu, Sulawesi Tengah", Aspirator. 2011.3 (2) 82-88

[37] Waluyo, B., "Pengaruh Penggunaan Cahaya Buatan Terus Menerus Terhadap Perilaku Aedes Menghisap Darah", Jurnal Kesehatan Masyarakat Indonesia. 2011.7 (1): 40

[38] Widjana, D. P. Sudarmaja. M \& Sutisna. P., "The Fauna of Aedes Mosquito and Its Potential Role in the Transmission of Dengue Hemorrhagic Fever in the Hamlet of Graha Kerti and Kerta Petasikan, Denpasar", Jurnal Kedokteran Yarsi. $2012.20(2): 81-86$

[39] Widyawati., Irene. F., Nitya., Syaukat. S., Rudy. P., Tambunan., Tri E. B \& Soesilo., "Penggunaan Sistem Informasi Geografi Efektif Memprediksi Potensi Demam Berdarah Di Region Endemik", Makara Kesehatan. 2011. 15 (1): $21-30$

[40] Wurisastuti, T., "Perilaku Bertelur Nyamuk Aedes aegypti pada Media Air Tercemar", Jurnal Biotek Medisiana Indonesia . 2013. 2 (1):25 - 32

[41] Yudhastuti, Z \& Vidiyani, A., "Hubungan Kondisi Lingkungan, Kontainer, Dan Perilaku Masyarakat Dengan Keberadaan Jentik Nyamuk Aedes Aegypti Di Daerah Endemis Demam Berdarah Dengue Surabaya “, Jurnal Kesehatan Lingkungan. 2005. 1 (2): 1. 